\title{
PENERAPAN DAM IBADAH HAJI DALAM PERSPEKTIF ISLAM
}

\author{
Mahfudzi \\ UIN Syarif Hidayatullah Jakarta \\ Email : mahfudzifarah@gmail.com
}

\begin{abstract}
ABSTRAK
Al-Qur'an dan As-Sunnah merupakan pedoman hidup yang mampu menjawab tantangan kehidupan manusia, sehingga menjadikan manfaat dan maslahat yang merupakan tujuan dari amaliyah seorang muslim. Islam adalah agama rahmatan lil'alamin, artinya tiada satupun permasalahan di dalam kehidupan manusia itu berakhir dengan kebuntuan dan pasti ada jalan keluarnya yang tidak menyalahi sunnatullah dan sunnah rosulullah.

Tanpa disadari roda dunia dalam peradaban Islam sudah seperti yang kita saksikan sekarang ini, sejak dicetuskan oleh pembawanya yaitu Nabi Muhammad SAW, Islam tidak pernah tergelincir rodanya sampai hari ini dan tetap berjalan dalam koridornya secara vertikal. Di era globalisasi yang serba bersentral kepada sains dan tekhnologi, maka kita harus benar-benar cerdas mengamalkan Islam secara utuh (menyeluruh), tentunya yang bersumber dari Al-Qur'an dan As-Sunnah.
\end{abstract}

Kata kunci : Islam, Ibadah Haji, praktek dam

\begin{abstract}
Al-Qur'an and As-sunnah able to answer the human life challange so it can bring the benefits which is form of purpose from charity of muslim. Islam is "rahmatan lil'alamin", it means there is no set of problem in human life become extinct without the solution. Furthermore, all the human problems have the solution which is not blamed to sunnatullah and sunnah rosulullah.

In addition, Without prejudice, the wheel of world in Islam civilization has been known at this day. Since Islam sparked by Muhammad SAW, Islam never makes a slip the wheel until at this time. The wheel is still exist and keep moving in vertical. However, in this globalization era which is science and technology as a central in human life, so we have to capable practice Islam perfectly and Al-Quran, As-Sunnah become a source.
\end{abstract}

Keywords : Islam, Ibadah Haji, Practice Dam 


\section{PENDAHULUAN}

Pada realitas yang ada bahwa Syariat Islam dalam pengamalannya selalu melihat kepada situasi dan kondisi yang terjadi atau selalu mengikuti kepada 'illat permasalahan yang telah terjadi di masyarakat, tetapi hal tersebut bukan berarti syariat Islam itu bisa dipermainkan semaunya dan bisa diubah-ubah seenaknya sesuai keinginan penganutnya demi kepentingan yang beraneka ragam. Syariat Islam sangat istiqomah dan sangat mengerti kondisi penganutnya. Seperti dijelaskan dalam qoidah ushul fiqh.

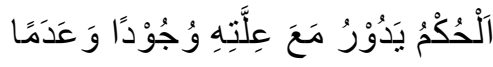

Artinya: Hukum itu berputar berdasarkan 'Ilatnya, dalam bentuk adanya hukum atau tidak adanya hukum.

Pertama permasalahan minuman keras.Sudah dinaskan di dalam AlQuran dan As-Sunnah bahwa hukum minuman keras adalah haram dan termasuk dosa besar.

Firman Allah SWT ${ }^{1}$

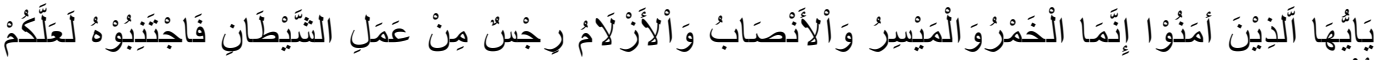

Artinya: Hai orang-orang yang beriman,sesungguhnya khamar, berjudi, (berkorban) untuk berhala, megundi nasib dengan panah adalah termasuk perbuatan setan, maka jauhilah perbuatan tersebut agar kamu mendapatkan keberuntungan

Nabi bersabda:

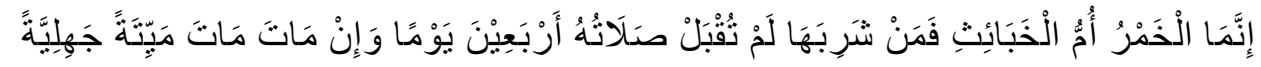

Artinya: minuman keras itu biangnya najis, barang siapa meminumnya maka tidak akan diterima sholatnya selama 40 hari, dan apabila mati maka matinya dalam keadaan jahiliyyah.

Itulah dua dalil yang berisi tentag diharamkannya minuman keras, tetapi bagaimana dengan orang muslim yang tinggal didaerah pegunungan es,dikutub utara seperti orang eskimo.sementara kehidupannya menuntut dirinya untuk minum khamar sebagai penghangat badan maka Islam menjawab tantangan tersebut berdasarkan qoidah ushul fiqh yaitu:

$$
\text { الَضَّرُوْرَاتُ تُبُيْحُ الَْحْظُوْرَاتِ }
$$

Artinya: keadaan darurat membolehkan melakukan yang diharamkan.

Permasalah yang ke dua adalah tentang Menyamak Kulit bangkai. Sabda nabi:

\footnotetext{
${ }^{1}$ QS.Al-Maidah:90
} 


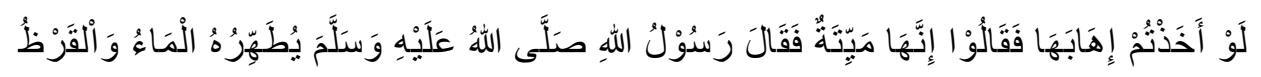

Artinya: ambillah olehmu kulitnya, mereka menjawab ya rosul ini bangkai kambing rosul menjawab sucikan dengan air dan dengan sesuatu yang kesed/ kasar

Kondisi pada waktu itu belum ada sabun, seandainya sudah ada sabun maka rosulullah mungkin menyuruhnya dengan sabun. Apakah menyalahi syariat seandainya menyamak kulit bangkai dengan sabun? Maka syariat islam sebagai rahmatan lil'alamin menjawab permasalah tersebut bahwa boleh saja mencuci kulit bangkai dengan sabun, sebab prinsipnya adalah bersih, suci, manfaat dan maslahat.

Permasalahan yang ke tiga adalah tentang Bersiwak.Bersiwak adalah perbuatan yang disunahkan untuk setiap aktifitas kebajikan. Sabda nabi:

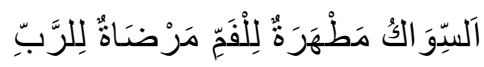

Artinya: siwak itu mensucikan mulut dan mendapatkan ridho Allah(H.R. Ahmad dan Nasai dari 'Aisyah)

Siwak disunahkan memakai kayu arok, betapa sulitnya mencari kayu arok di Indonesia, dan seperti apa bentuknya, sampai sekarang banyak orang tidak mengetahuinya mungkin yang dimaksud kayu arok itu adalah susur. Setiap jama'ah haji yang pulang dari tanah suci makkah sering kali suka membawa oleh-oleh diantaranya adalah susur yaitu berupa akar kayu berwarna putih dan kering, di makkah biasa dijual oleh orang-orang badawy, satu ikatnya bisa dibeli dengan harga kurang lebih 5 real, padahal akar-akar kayu tersebut sudah termasuk afkiran sama sekali sudah tidak digunakan oleh orang-orang arab.

Bangsa Indonesia terutama kakek-kakek yang sudah tua suka mengikatkan susurnya dengan tasbih dan digunakan setiap akan sholat dan tidak dicucinya terlebih dahulu, hal semacam ini sudah jelas bisa dikategorikan najis dan tidak higienis dan bisa menimbulkan penyakit. Maka penggunaan susur seperti itu sudah tidak termasuk sunnah lagi, karena najisdan menjijikan bahkan juga bisa menimbulkan penyakit. Adapun siwak yang asli rasanya hangat dan mengandung air dan baunya harum, dan harganya jauh lebih mahal dari akar kayu arok yang afkiran tadi, ukuran kurang lebih $10 \mathrm{~cm}$. Harganya sekitar kurang lebih 10 real sehingga manfaat penggunaan susur atau siwak akar kayu arok yang asli perbandingannya sama dengan penggunaan sikat gigi dan pasta giginya.

Sehingga dapat dikatakan bahwa menyikat gigi sama dengan bersiwak yaitu dengan menggunakan kayu arok dan Islam mampu menjawab yaitu jika ingin mendapat pahala sunnah maka siwak bisa diganti dengan sikat gigi dan pasta gigi. Seandainya dahulu sudah ada sikat dan pasta gigi maka rosulullah SAW mungkin akan menganjurkannya, sebab prinsip pada siwak itu adalah bagaimana gigi itu bersih, suci dan mendapatkan manfaat dan maslahat.

Permasalahan yang ke empat adalah memandikan janazah. Rosulullah SAW bersabda dalam salah satu hadisnya: 


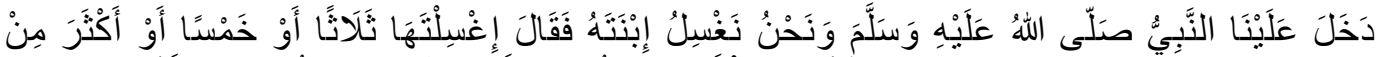

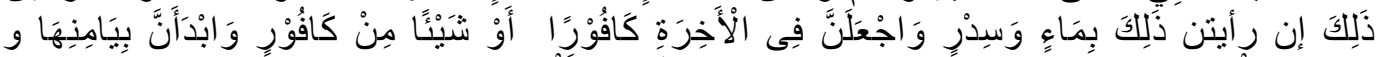

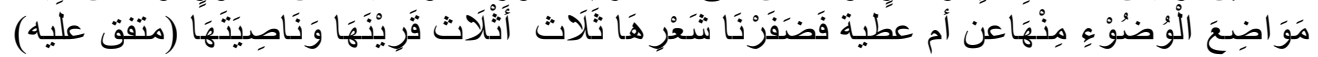

Artinya: rosul SAW datang kepada kami pada waktu itu kami sedang memnadikan putri beliau siti zainab yang meninggal dunia, kemudian beliau bersabda: mandikanlah dia dengan $3 x$ atau $5 x$ atau atau yang lebih daripada itu jika kamu sekalian menganggap baik mandikanlah dengan air dan dengan daun bidara dan pada kali yang terakhir sempurnakanlah dengan kafur atau sedikit kafur dan mulailah dengan bagian kanan tempat wudhu dari badannya. Umi 'atiyah berkata: kemudian kami menyanggul rambut kepalanya menjadi tiga bagian sanggul, bagian kanan dan kiri kepala serta bagian ubun-ubunnya .

Di dalam hadist tersebut rosulullah SAW, menganjurkan dengan sidrun yaitu kayu bidara dan sedikit ditaburi kafur, mungkin kebanyakan orang di Indonesia tidak mengenal kayu bidara, sekalipun ada, mungkin didaerah tertentu yang susah untuk mencarinya, Maka hal ini menjadi tantangan yang harus dijawab oleh syariat Islam, perlu diketahui bahwa pada waktu itu belum ada sabun, seandainya sudah ada sabun mungkin rosulullah menganjurkan untuk pakai sabun. Jadi jawaban syariat secara tepat dan benar lebih baik menggunakan sabun sebagai pengganti sidrun/ kayu bidara, kemudian yang dimaksud dengan kafur didalam hadist di atas adalah kafur barus(kamper),sebab prinsip memandikan mayat adalah agar bersih, suci dan mendapat manfaat dan maslahat. Contoh-contoh di atas membuktikan betapa rukhsoh dan tasamuhnya (toleransi) Islam terhadap pengamalan hukum syariat. Dan bagaimanakah jika contoh-contoh tersebut di atas di qiyaskan dalam permasalahan yang berkaitan dengan Praktek ekonomi dalam dam haji agar membawa manfaat dan maslahat bagi umat muslim.

\section{PEMBAHASAN}

Dam berasal dari bahasa Arab yang berarti darah. Namun dalam arti luas adalah bentuk pelanggaran dalam ritual ibadah haji seperti: ketika sedang wukuf di Arafah melakukan pembicaraan yang kotor atau perbuatan yang melanggar seperti memotong pohon, mengambil daun, membunuh binatang. Sementara itu, Dam karena proses ibadah misalnya Sistem Haji Tamattu'. Pada sistem ini, jamaah haji harus memotong kambing atau berpuasa 10 hari yakni tiga hari dilakukan di Makkah dan tujuh hari dilakukan di Indonesia. 'Di Indonesia harga kambing bisa mencapai Rp 1 juta lebih, sedangkan di Makkah hanya sekitar Rp 300 real bila belum banyak jamaah haji datang. Namun bila jamaah haji sudah berdatangan ke Makkah harga seekor kambing mencapai 475 -500 real. Sebaiknya dam dibayarkan setelah melakukan umroh dan yang lebih afdol adalah setelah jumrah Aqobah sampai masa haji selesai. Dan ini bisa dilakukan lewat bank, dan lebih baik lagi langsung membayar di tempat pemotongan hewan atau dititipkan kepada karom (ketua ronbongan) atau ketua kloter untuk pembelian hewan Dam di pasar pemotongan hewa Kaqiyah atau Mina, Secara umum Dam berarti Denda atau tebusan bagi jama'ah haji atau umrah yang melakukan pelanggaran terhadap ketentuan atau peraturan yang telah ditetapkan oleh pihak penyelengara haji 
dan umroh. seperti melakukan larangan-larangan ihram atau tidak dapat menyempurnakan wajib haji seperti mabit di Mina atau Muzdalifah.

Ibadah haji merupakan ibadah yang dilakukan sejak zaman Nabi Ibrahim AS yang dilaksanakan sampai sekarang. Namun haji pada saat itu disalah gunakan yaitu untuk berbangga-banggaan dan memamerkan sukunya, sehingga pada saat permulaan haji pun sudah ada pengeluaran dam karena adanya pelanggaran. Pelanggaran tersebut di sebabkan karena proses pelaksanaan ibadah haji diantaranya: 1. Haji Ifrad merupakan pelaksanaan ibadah umrah setelah melakukan kewajiban haji, maka disunatkan untuk menyembelih qurban. Biasanya haji ini dilakukan oleh jama'ah Indonesia yang datang dengan kelompok terbang (kloter) akhir, sehingga saat tiba disana, mereka langsung bisa melaksanakan haji, setelah melaksanakan haji, mereka menunggu kepulangan dengan melaksanakan umrah. 2. Haji qiran adalah proses ibadah haji dan umrah yang dilakukan bersamaan. sampai seluruh ritual yang dijalani, seperti ihram, thawaf, sa'i, melempar jumrah atau mabit yang diniatkan untuk haji dan umrah. Begitu juga dengan kewajibankewajiban yang lain. Kecuali saat wukuf yang merupakan kewajiban haji.maka Pelaksaanaan Haji ini wajib mengeluarkan dam. 3. Haji tamattu yaitu pelaksanaan ibadah Haji ini lebih banyak dilakukan oleh orang-orang Indonesia. Saat mereka datang ke Arab Saudi, disana belum waktunya untuk melakukan ibadah haji sehingga mereka biasanya melakukan ihram untuk umrah, langsung dari miqatnya. Setelah selesai melaksanakan ihram dan berakhir pada tahallul atau memotong rambut, maka para jamaah ini menunggu sampai tiba waktunya haji pada hari Tarwiyah dan Arafah pada tanggal 8-9 Dzulhijjah. Dan mereka melaksanakan ihram lagi untuk proses ibadah haji. Sehingga para jamaah ini melakukan 2 kali ihram. Proses haji tamattu ini wajib untuk mengeluarkan dam.

Meninggalkan nusuk/haji, seperti melempar jumrah, ihram tidak dilakukan dari miqat. Tidak melaksanakan wukuf di padang arafah dari pagi sampai malam. Datangnya jamaah haji bisanya tanggal 8 malam 9 dzulhijjah dan menunggu sampai siang arafah sampai malam 10 dzulhijjah. Juga dengan mabit di Mina atau Mudzdalifah, jika tidak dilaksanakan maka terkena dam.Apabila tidak melaksanakan thawaf wada' maka harus didenda.dam tersebut pembayarannya dengan cara tartib seperti dam haji tamattu, makna tartib yaitu harus menyembelih seekor kambing dan tidak bisa dialihkan pada pilihan lain kecuali jika tidak mampu melaksanakannya dengan sebab harganya mahal atau karena uzur lain yang bisa dipertimbangkan menurut syara seperti tidak ada hewan ternak yang disembelih dll.

Maka dalam kondisi seperti itu dapat dialihkan pada puasa 3 hari yang dilaksanakan pada waktu pelaksanaan haji dan tujuh hari setelah pulang ketanah air masing-masing. jika tidak melaksanakan puasa maka harus diganti dengan bersodaqoh kepada 10 orang miskin dan setiap 1 orang miskin diberi 1 mud dan pembayarannya tidak dikhususkan kepada fuqoro makkah tetapi juga fuqoro negara lain, seperti yang dijelaskan dalam kitab bugyatul musytarsyidin hal. 70 atau kitab kifayatul akhyar hal.233 yaitu:

$$
\text { وَلَا يُخْنَصنُ الطعامُ الو اقعُ بدلاً عن صومِ التَّمَتُعْعِ بفقراء الحرم }
$$

Artinya: dan tidak dikhususkan penyerahan dam berupa makanan yang ada sebagai pengganti dan puasa tamattu kepada orang fakir makkah. 
Dam wajib bisa disebabkan karena bersenang-senang dengan memakai wewangian saat haji, (yang boleh adalah sebelum ihram). Lalu bercukur atau tahallul belum waktunya, maka wajib mengeluarkan dam. Dam tersebut pembayarannya dengan cara takhyir yaitu dapat memilih antara menyembelih kambing atau puasa 3 hari atau bersodaqoh 3 sho' untuk 6 orang miskin.. sebagaimana firman Allah SWT.

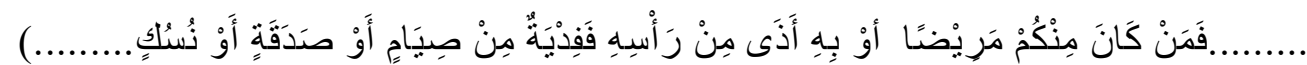

Artinya: jika ada diantara kamu yang sakit atau ada gangguan dikepalanya lau ia bercukur, maka wajiblah berfidiyah yaitu berpuasa atau bershodaqoh atau berkorban.......(QS. Al-Baqoroh:196)

Juga di dalam hadist rosulullah SAW. Beliau bersabda:

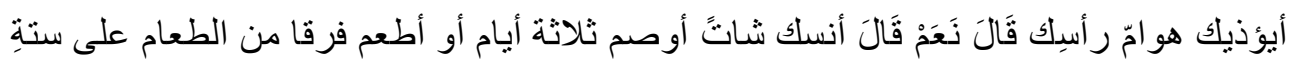

مساكين

Artinya: apakah kamu terganggu rayapan yang mengeriyap dikepalamu?ka'ab menjawab iya rosulullah.rosul bersabda: berqurbanlah kamu satu ekor kambing atau berpuasa tiga hari, atau bersodaqoh makanan satu wadah kepada enam orang miskin(H.R. Bukhori Muslim)

Dam wajib juga bisa disebabkan karena tindak pelanggaran kriminal di tanah haram (Melakukan jinayah), seperti mengganggu binatang waktu ihram, atau saat ihram memotong tanaman disana.. dam tersebut pembayarannya dengan cara takhyir yaitu mengganti seperti yang dibunuhnya atau dengan uang seharga binatang yang dibunuh untuk dishodaqohkan atau memilih puasa yang jumlah harinyadisesuaikan dengan jumlah harga dam dan untuk puasa satu hari nilainya sama dengan satu mud.

Firman Allah SWT

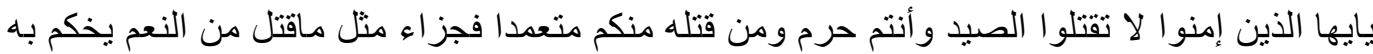

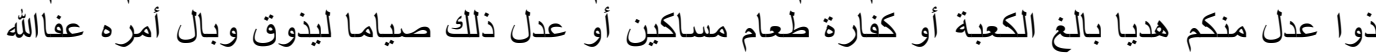
عما سلف ومن عاد فينتقم الله منه و الله عزيز ذالف ذو انتقام

Artinya: hai orang-orang yang beriman janganlah kamu membunuh binatang buruan, ketika kamu sedang ihram, barang siapa diantara kamu membunuhnya dengan sengaja maka dendanya adalah mengganti dengan binatang ternak yang seimbang dengan binatang yang dibunuhnya, menurut putusan dua orang yang adil diantara kamu sebagai hadyad yang dibawa sampai ke ka'bah atau dendanya membayar kafarat dengan memberi makan orang miskin atau berpuasa seimbang dengan makanan yang dikeluarkan itu, supaya dia merasakan akibat buruk dari perbuatannya. Allah telah memaafkan apa yang telah lalu. Dan barang siapa yang kembali mengerjakannya niscaya Allah akan menyiksanya Allah maha kuasa yang mempunyai kekuasaan untuk menyiksa(QS.Al-Maidah: 95)

Dam wajib juga bisa disebabkan karena dihadang oleh musuh atau ada dalam peperangan. 
Sebagaimana firman Allah SWT:

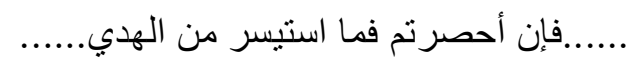

Artinya: ....... jika kamu terkepung atau terhalang oleh musuh atau karena sakit, maka sembelihlah korban yang mudah didapat........ (QS. AlBaqoroh:196)

Dam wajib juga bisa disebabkan karena berjima' maka pembayarannya dengan cara takhyir yaitu dengan menyembelih seekor unta, atau menyembelih seekor sapi atau menyembelih tujuh ekor kambing atau bershodaqoh seharga binatang unta, atau berpuasa yang jumlah harinya disesuaikan dengan jumlah harga dam (satu hari puasa nilainya sama dengan satu mud. Demikianlah penjelasan tentang dam yang hukumnya berlaku sampai sekarang, dengan tidak ada perubahan sesuai dengan dalil Al-Qur'an dan Al-Hadist dan juga pendapat para ulama. Namun penulis ingin mencoba mencari jalan keluar agar mendapatkan yang lebih manfaat dan maslahat dari dam tamattu atau qiron atau dam-dam lain untuk kepentingan umat islam umumnya, dan umat islam indonesia khususnya.

Pada Tanggal 10 Dzulhijjah yang disebut dengan hari nahar atau yaumul 'ied, di manhar atau jabal qurban terlihat jelas dan dapat disaksikan ribuan ekor kambing, unta juga sapi tergeletak yang telah disembelih secara syar'i tanpa dipedulikan dan tumpukan binatang ternak tersebut yang sudah disembelih didorong bulldozer diangkat keatas truk untuk dibuang kegunung, Apakah pemandangan seperti ini akan dibiarkan berlanjut sampai hari kiamat? Bukankah perbuatan seperti itu tergolong perbuatan orang yang memubazirkan makanan? jelas ini adalah pemubaziran dan Allah memposisikan orang-orang yang memubazirkan makanan adalah saudaranya syetan.

Firman Allah SWT

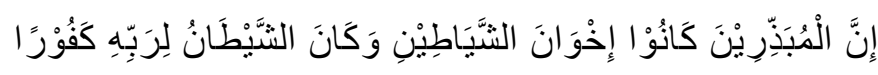

Artinya : sesungguhnya pemboros itu saudaranya syetan dan syetan sangat ingkar kepada Allah (QS.Al-Isra':27)

Binatang ternak yang diqurbankan dari hasil keimanan kepada Allah dan benar-benar halal karena dipotong sesuai syariat Islam tiba-tiba dimubazirkan begitu saja. Bukankah hal itu dianggap sampah? Sungguh tidak Islami bahkan secara serius akan mendapat ancaman Allah bahwa orang seperti itu termasuk saudaranya syetan.

Memang tidak ada satupun ulama yang membahas tentang pemubaziaran dari hasil dam tersebut mengingat pada waktu itu masih seimbangnya para jama'ah haji dengan penduduk kota makkah yang tergolong fakir bahkan telah membudaya bahwa kambing tersebut merupakan lauk pauk yang pokok, mungkin saja mereka pada waktu itu ada yang mengambil dam tersebut begitu pula para jama'ah haji pun turut mengambil daging dam tersebut. Atau karena masih sedikitnya jama'ah haji dari penjuru dunia yang datang ke kota makkah karena sulitnya transportasi baik laut 
ataupun udara, ditambah lagi dengan kekacawan perang dimana-mana dan ketidaksetabilan ekonomi, politik, sosial pada waktu itu, hal itu memungkinkan sulitnya untuk melaksanakan ibadah haji termasuk negeri kita Indonesia.

Pada abad ke 17 bangsa Indonesia mungkin hanya 10 atau 20 yang berangkat melaksanakan ibadah haji, konon didalam cerita mereka bahwa berangkat haji dengan perahu kayu dengan menempuh perjalanan yang cukup lama, mungkin sambil berdagang rempah-rempah begitupula orang arab datang ke Indonesia pada abad yang sama sambil berdagang, hal ini menandakan bahwa penduduk dunia masih tergolong sulit dalam perekonomian begitupula orang arab itu sendiri. Pada abad 17 kebelakang tidak ada pemubaziran tentang dam maka dengan sebab itu tidak ada satupun ulama yang membahas tentang pemubaziran dari hasil dam karena memang daging dam tersebut langsung dikonsumsi sehingga tidak ada pemubaziran.

Dari abad ke 18 berangsur-angsur dunia berusaha menstabilkan keamanan, ekonomi ,sosial, politik, budaya dan kebersamaan hidup hingga terjadilah seperti sekarang ini yang disebut dengan era globalisasi, dimana segala kebutuhan hidup serba teratasi secara cepat dan singkat sehingga mencapai kemudahan disegala bidang dan untuk pelaksanaan ibadah hajipun mudah dan cepat tentunya dengan alat transportasi yang canggih baik udara maupun laut, disamping perekonomian sudah mapan dan keamanan sudah terjamin maka terjadilah pembludakan jama'ah haji hingga mencapai jutaan orang dalam setahunnya seperti negara Indonesia sudah mencapai 250 ribu orang jama'ah bahkan daftar tunggu (waiting list) untuk setiap tahunnya sudah banyak.

Maka seandainya jumlah jama'ah haji seluruh dunia sekarang mencapai 4 jutaan orang jika yang melaksanakan dam umpamanya 3 juta orang sesuai dengan niat hajinya, maka seperti apa gundukan binatang ternak seperti kambing,unta, dan sapi yang tergeletak di manhar (tempat pemotongan qurban) dari hasil pemotongan dam tersebut. Seandainya jumlah jama'ah haji indonesia tahun ini mencapai 250 ribu orang jika dikalkulasikan dengan nilai harga seekor kambing untuk dam dirupiaahkan. Misalnya satu juta rupiah/ ekor maka kurang lebih mencapai jumlah 250 milyard rupiah pertahun.

Seandainya jumlah uang tersebut seluruhnya dibelikan kambing untuk dam maka alangkah terperangahnya melihat gundukan 250 ribu ekor kambing tergeletak dimanhar hasil pemotongan dam jama'ah haji indonesia, kemudian kambing-kambing itu dibuang kegunung begitu saja untuk makanan lalat,burung-burung bangkai berikut binatang buas, seolah-olah bagaikan sampah tak berguna yang menjijikan. Sebagai seorang muslim yang sehat dan bertakwa kepada Allah SWT maka tidak pernah terlintas dalam pikiran berkeinginan menjadikan dam haji untuk lebih manfaat dan maslahat bagi umat daripada menjadi sampah yang terbuang.

Sebagai solusi dalam permasalahan ini, penulis akan mengungkapkan sebuah hadist rosulullah SAW pada waktu itu rosulullah menugaskan mu'az bin jabal untuk menjadi gubernur di yaman, lalu mu'az bertanya kepada rosulullah SAW.

يا رسول الله كيف تفعل إذا جاءنا أمرلم نجده فى كتاب و لا سنة فقال صلى الله عليه سلوا الصالحين واجعلوه شورى باله كينهم 
Artinya: ya rosulullah apa yang kami lakukan bila datang kepada kami perkara agama dan kami tidak menemukan perkara itu dalam al-qur'an dan as-sunnah? Rosulullah menjawab: tanyalah orang-orang sholeh lalu jadikanlah perkara itu dalam musyawarah dengan mereka( itthafussadatil muttaqiin hal.172)

Hadist tersebut membuktikan bahwa rosulullah saw sangat percaya kepada para ulama untuk membahas segala permasalahan didalam syariat islam demi tercapainya kemaslahatan dan kemanfaatan untuk umat, sekalipun masalah tersebut tidak ada dalam dalil al-qur'an dan al-hadist sesuai dengan keterangan bahwa ulama adalah pewaris para nabi dan rosul.

$$
\text { العلماء ورثنة الأنبياء }
$$

Pernyataan tersebut merupakan ajakan kepada para ulama untuk memusyawarahkan masalah dam tersebut, segala apa saja yang tertuang di dalam tulisan ini semuanya hanyalah sebuah wacana yang perlu dikaji dan diteliti sebagai bahan pertimbangan dan rujukan didalam kitab kifayatul akhyar juz I Hal 233 dalam tatacara membayar dam sebagai berikut yaitu: 1 . Tartib (urutan), 2. Takhyir (pilihan) 3. Ta'diil ( pengalihan) yaitu:

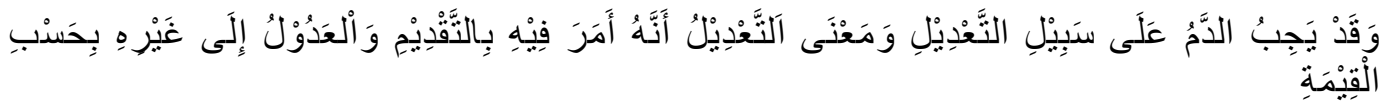

Artinya : bisa terjadi dam itu wajibnya secara ta'dil, artinya orang itu dianjurkan menaksir harga dam lalu berpindah kepada yang lainnya menurut nilai taksiran harga dam tersebut.

Keterangan ini tentu bertujuan untuk mengarahkan dam haji kepada yang lebih bermanfaat dan maslahat untuk umat, mungkin 'ulama ini juga telah mengetahui akan terjadinya pemubaziran ternak hasil dam atau ulama ini pula telah mengetahui akan terjadinya kekurangan ternak dikemudian hari sehingga membolehkan melaksanakan dam dengan nilai uang .

Pada kalimat Wal 'Aduul Ila Ghoirihi, artinya digantikan atau ditukarkan dengan yang lainnya. Yang dimaksud dengan yang lainnya adalah seperti roti dan makanan lainnya.disini kita boleh memprediksikan seandainya jumlah uang dam 250 milyard rupiah dibelikan roti atau nasi atau makanan lainnya kemungkinan besar akan terjadi pemubaziran kembali dan akan menjadi sampah yang tidak berguna. Bagaimana seandainya istilah Wal 'Dul Ila Ghoirihi dialihkan kepada yang lebih manfaat dan maslahat seperti bentuk uang lalu tidak dibelikan roti dan makanan yang lainnya, tetapi di kelola untuk pembangunan masjid, madrasah atau rumah sakit dan membantu fuqoro dan masakin, Penulis mengira cara seperti ini lebih terhormat, bermartabat, bermanfaat dan maslahat, sebab tujuannya adalah untuk membina umat Islam agar menjadi orang yang bertaqwa.

Firman Allah SWT dalam surat Al-Hajj ayat 37 yang berbunyi:

$$
\text { وبشر المحسل اللهنين لحوها و لا دماؤ ها ولكن يناله التقوى منكم كذلك سخر ها لكم لتكبروا الله على ما هداكم }
$$


Artinya: daging daging unta dan darahnya itu, sekali-kali tidak dapat mencapai keridhoan Allah SWT tetapi ketaqwaan dari kamulah yang dapat mencapaiya.demikianlah Allah telah menundukannya untuk kamu supaya kamu mengagungkan Allah terhadap hidayah kepadamu dan berlah kabar gembira kepada orang-orang yangnberbuat baik.

Pada ayat tersebut di atas sangat jelas sekali bahwa yang dinilai oleh Allah adalah hanya ketaqwaan seseorang yang beramal. Adapun binatang qurban seperti unta ,kambing dan sapi itu seolah-olah hanya merupakan media untuk meraih ketaqwaan kepada Allah SWT. Berarti semua jama'ah haji Indonesia yang menyerahkan uang untuk dam sesuai harga ternak dengan ikhlas dan karena taqwa kepada Allah tanpa melihat wujud kambingnya dan tidak mengetahui dimana disembelihnya adalah orang yang diterima amalnya.

Contoh: para jama'ah haji Indonesia pada waktu menyerahkan uang dam kepada panitia, hampir rata-rata jama'ah haji indonesia melaksanakan ibadah haji dengan cara haji tamattu', biasanya mereka waktu datang ke makkah mereka langsung melaksanakan umroh lalu istirahat dipondokan sambil berganti pakaian, tidak lama kemudian datang petugas kloter untuk menyerukan kepada jama'ah agar menyediakan uang untuk pembayaran dam sesuai harga yang telah ditentukan misalnya 350 real, lalu panitia mencatat satu persatu nama setiap jama'ah. Cara-cara seperti ini hampir setiap tahun dilakukan oleh jama'ah haji. Bagaimana tentang uang yang sudah dipegang oleh panitia, apakah uang itu akan dibelikan kambing, unta atau sapi yang akan dibuang sia-sia.atau uang itu akan dikemanakan, sementara orang yang telah memberikan uang dam tersebut dengan penuh ketaqwaan. Silahkan kepada para umat Islam berfikir sejenak ,akan digunakan untuk apa uang yang sangat besar itu yang jumlahnya kira-kira sekitar 250 milyard pertahun. Dengan tujuan agar lebih bermanfaat dan maslahat bagi umat Islam.

Bagaimana dengan mafia dalam dam haji, seandainya kejujuran dan jiwa amanah dimiliki oleh setiap orang, maka tidak akan ada istilah mafia dalam kehidupan ini, ternyata mafia juga ikut berkecimpung di dalam peribadatan dam haji, tetapi disini tidak akan terlalu jauh Menyoroti Hal Tersebut karena khawatir muncul su'uzhon, namun sebagaim bukti adanya mafia dalam dam haji bisa diperlihatkan dalam jumlah ternak yang disembelih di manhar yang sangat tidak seimbang dengan jumlah kehadiran para jama'ah haji ditanah suci makkah. Seandainya jumlah jama'ah haji yang melakukan dam misalnya sebanyak 2juta orang. dimana disembelihnya ternak-ternak tersebut, sementara dimanhar yang memang disunahkan tempat penyembelihannya hanya terlihat,kemana yang lainnya. walaupun pelaksanaan dam haji ada yang melalui bank Al-Roj'i. Mudah-mudahan melalui upaya wacana pengalihan sistem dam, akan mampu menghilangkan praktek-praktek mafia yang sangat tidak Islami dan mudah-mudahan bila terwujud wacana ini nantinya akan dapat dirasakan kemaslahatannya oleh seluruh umat Islam di Indonesia.

Banyaknya jamaah haji yang tidak tahu tata cara membayar dam, seperti di mana tempat untuk membeli kambing, menyembelihnya, termasuk kendala bahasa saat melakukan transaksi. Mempertimbangkan berbagai kesulitan jama'ah tersebut, maka pembayaran dam secara kolektif akan lebih memudahkan para jamaah haji untuk memenuhi semua kewajibannya dan 
menjadi haji mabrur. tetapi Kementerian Agama (Kemenag) menyatakan belum bisa memutuskan teknis pembayaran dam (denda) haji secara kolektif. Karena pembayaran dam merupakan kewajiban sepenuhnya jamaah haji tamattu' maupun qiran.

Meskipun, pembayaran dam kolektif merupakan teknis yang efektif untuk menjaga dan melindungi para jamaah haji. Namun hal itu diperlukan cara yang tepat terkait pengambilan dana dam. "Apakah itu dari uang living cost para jamaah atau digabung dari ONH (ongkos naik haji.Hal itu, harus dibicarakan lebih lanjut karena itu menyangkut uang jamaah haji. "Tugas pemerintah hanya mengawasi dan melindungi pembayaran dam jamaah haji. Sedangkan Teknisnya diserahkan kepada persetujuan jamaah sendiri karena ituuang mereka. Sebelumnya, Sekretaris Komisi Fatwa Majelis Ulama Indonesia (MUI) KH Asrorun Ni'am Sholeh mengatakan bahwa MUI telah menetapkan fatwa tentang pembayaran dam atas haji tamattu' dan qiran secara kolektif.

Penetapan fatwa dilatarbelakangi adanya kebijakan pemerintah yang mengatur mekanisme Pemberangkatan jamaah hajidan pemerintah berjanji akan mengawasi proses pembayaran dam yang sudah ditetapkan besarannya, yakni sekitar 475 riyal atau sekitar Rp1,8 juta dengan kurs Rp3.800 untuk 1 riyal. Sebab, selama ini sering kali ada oknum yang menawarkan pembayaran dam di bawah perkiraan nilai yang sudah ditetapkan Ada yang menjanjikan bisa membayarkan dam dengan murah yakni, 300 riyal.Tetapi ada juga yang menawarkan bisa membayarkan dam, namun dengan harga hingga 700 riyal.

Ternyata Pada praktiknya, pembayaran dam tidak terkoordinasi dengan baik sehingga menyulitkan jamaah. Bahkan pendistribusian dam pun tidak optimal serta rawan penyimpangan. Jika masalah dam diserahkan sepenuhnya kepada jama'ah maka dikhawatirkan akan banyak oknum yang menawarkan Dam dengan harga yang murah. Hal ini bisa terjadi dengan berbagai motif, bisa hewan yang dibeli dan disembelihkan pada waktu yang tak sesuai dengan syar'i, tentu saat harga murah. Kemungkinan lain adalah penipuan yakni uang yang terhimpun tidak dibelikan dan disembelihkan, atau dibeli dan disembelih sebagian saja. Jamaah terkadang tidak cermat melihat apakah hewan itu telah dibeli dan disembelih atau belum. Jama'ah kadang ikhlas dan percaya, karena yang penting baginya ia sudah membayar Dam tersebut.

\section{PENUTUP}

Di dalam kitab kifayatul akhyar juz I Hal 233 dalam tatacara membayar dam sebagai berikut yaitu: Tartib (urutan), Takhyir (pilihan) Ta'diil (pengalihan) Selama ini mayoritas jama'ah haji Indonesia mengeluarkan dana untuk pembayaran dam, tetapi tidak pernah ada akuntabilitas atau tidak adanya pertanggung jawaban tentang bagaimana implementasi dari pembayaran dam bahkan yang terjadi adalah adanya manipulasi, penyalahgunaan, penipuan, penyelewengan dari sejumlah oknum dengan memanfaatkan ketidaktahuan sebagian jama'ah haji Ind onesia. Hal itu terjadi bahkan selalu terrjadi karena penyelenggara haji dan badan yang terkait belum memiliki mekanisme sistem yang bisa dipertanggungjawabkan mengenai uang yang telah ditashorufkan untuk dam itu benar-benar dibelikan lalu dagingnya dimanfaatkan oleh yang berhak. Walaupun dam itu tanggung jawab personal, dan karena implikasi sosialnya sangat tinggi maka perlu 
adanaya pengelolaan yang baik agar amaliyah jama'ah membawa manfaat dan maslahat.

\section{DAFTAR PUSTAKA}

Al-Qur'ân Al-Karîm

Adhwa'ul Bayan fi Idhah al-Qu`ran bil Qur`an, Syaikh Muhammad Amin asy-Syinqithi, Darul Fikr.

Al-Bahtsul Amin fi Hadits al-Arba'in, diterbitkan dalam Majalah al-Jami'ah al-Islamiyyah edisi 41.

At-Targhib wat Tarhib, al-Mundziri.

Fadhlul Madinah, Syaikh Abdul Muhsin al-'Abbad.

Fatawa al-Lajnah ad-Daimah,

Majma' az-Zawa id wa Manba' al-Fawa`id, al-Haitsami, Maktabah al-Qudsi.

Majmu' Fatawa Syaikh Bin Baz, Muhammad asy-Syuwai'ir.

Mir'atul Mafatih Syarh Misykatil Mashabih, Abul Hasan al-Mubarakfuri, alJami'ah as-Salafiyyah.

Shahih at-Targhib wat Tarhib, al-Albani, Maktabah al-Ma'arif.

Silsilah al-Ahadits adh-Dha'ifah wal Maudhu'ah, al-Albani, Maktabah alMa'arif.

Takhrij Ahadits Ihya Ulumiddin, al-Hafizh al-'Iraqi, Darul 'Ashimah.

Majma' az-Zawaid 4/8, at-Targhib wat Tarhib 2/139.

Al-Bahtsul Amin fi Hadits al-Arba'in, diterbitkan dalam Majalah al-Jami'ah al-Islamiyyah edisi 41.

Silsilah al-Ahadits adh-Dha'ifah wal Maudhu'ah 1/540 no. 364, Majmu' Fatawa Syaikh Bin Baz 26/285, Fadhlul Madinah hal. 19, Fatawa al-Lajnah. 